\title{
Digestion of Tannin by Bacteria Enterobacter cloacae from the Gut of Indian Mole Cricket (Gryllotalpa krishnani)
}

Govindarajan RK ${ }^{1}$, Seemaisamy Revathi' ${ }^{1}$, Neelamegam Rameshkumar ${ }^{2}$, Muthukalingan Krishnan ${ }^{2}$ and Nagarajan Kayalvizhi*

${ }^{1}$ Department of Zoology, School of Life Sciences, Periyar University, Salem, Tamil Nadu, India

${ }^{2}$ Insect Molecular Biology Laboratory, Department of Environmental Biotechnology, Bharathidasan University, Tiruchirappalli, Tamil Nadu, India

\begin{abstract}
Insects are the most successful animal on earth; the gut microbes present might play an important role in food digestion as well as the interaction with hosts. In this study insect Gryllotalpa krishnani has been used to isolate the symbiotic associated organisms which play role in host metabolism, promote efficient digestion and to protect the host from the harmful microbes. In the present study, microorganisms were isolated from the gut of G. krishnani and characterized for tannase enzyme activity. It was observed that 5 isolates (TAH 6, TAH 13, TAH 36, TAH 38 and TAH 41) out of total 120 tested were able to show significant growth on tannic acid plate. Among these five potential isolates, strain TAH 41 exhibited maximum tannase activity in tannase plate assay and was selected for the further study. The bacterial strain TAH41 was analyzed for biochemical analysis, 16S rDNA sequencing and the result confirmed the strain as Enterobacter cloacae. HPLC analysis showed the formation two peaks representing gallic acid and glucose as a by-product FT-IR analysis also confirmed the same. The polyacrylamide gel electrophoresis (SDS-PAGE) and zymogram analysis showed the molecular mass of tannase enzyme in cell free extract was $\sim 45$ $\mathrm{kDa}$, the analysis suggested this tannase enzyme to be one of the smallest of the bacterial source, which could be attributed to the formation of di or tri-galloyl glucose. The present study was the first report $E$. cloacae with tannase activity from G. krishnani gut. E. cloacae which may endow the insect with some ecological advantages by enabling them to overcome the anti-nutritional effects of plant tannins.
\end{abstract}

Keywords: Insect G. krishnani; Tannase; 16S rDNA; HPLC; FT-IR; SDS-PAGE; Zymogram

\section{Introduction}

Tannin acyl hydrolase (E.C 3.1.1.20), which is commonly referred as tannase, is an enzyme that hydrolyzes the ester (depside) bond of the 3, 4, 5-trihydroxybenzoic acid (gallic acid) found in gallotannins, complex tannins and catechins. Tannase are extensively used in the preparation of instant tea, wine, beer, food, pharmaceutical industries and tanneries effluent degradation. Gallic acid, the major hydrolytic product of tannic acid, is used in food, cosmetics and adhesives in the synthesis of potent antioxidant, propyl gallate [1]. It has long been known that several fungi species such as Aspergillus sp. and Penicillin sp are capable of producing a larger amount of this enzyme for industrial use, the enzyme is invariably of fungal origin [2]. The fungi exhibit better activity for the degradation of hydrolysable tannins. However, a major problem in usage of fungal strain at industrial level is its relatively slow growth rate and genetic complexity. However, bacterial genera such as Bacillus, Streptococcus gallolyticus, Klebsiella, Lactobacillus and Pantonea have also the ability to degrade and hydrolyze natural tannins and tannic acid very efficiently $[3,4]$. On the other hand, the growth rate of bacteria is very high and they can be easily manipulated at the genetic level. The bacteria are also capable of living under extreme thermophilic conditions; therefore they may prove a potential source of thermo stable tannase enzyme $[5,6]$. The genomes of insects lack many of the catabolic enzymes necessary to digest food fully in order to extract energy source. Thus, insect gut microbes play a pivotal role in the digestion of fiber, cellulose, starch, lignin, tannin etc, to provide energy for the host $[7,8]$. Traditionally, digestion is described as the process by which food in the gastrointestinal (GI) tract is split into simpler absorbable compounds performed primarily by the digestive enzymes. However, what happens in the alimentary tract is only one part of a continuous process that also includes factors outside of the GI tract. In the present investigation, newly identified the insect, Gryllotalpa krishnani, were screened for tannase enzyme producing gut microbes and an able identified strain was Entreobacter cloacae, keeping these in view, we report the production and characterization tannase enzyme cell free extract of tannase from a newly isolated aerobic bacterial strain of Enterobacter cloacae.

\section{Materials and Methods}

The newly identified insect G. krishnani was collected in wet soil with near to a kitchen waste, Salem district, Tamil Nadu, India (latitude: $11.6500^{\circ} \mathrm{N}$, longitude: $78.1600^{\circ} \mathrm{E}$; elevation: $154 \mathrm{ft}(46.7 \mathrm{~m})$. The soil was buried up to $10-15 \mathrm{~cm}$ depth by a digger and a colony of this species was found beneath the soil. The insect was collected dissection in our laboratory conditions.

\section{Chemicals}

Trypton Soya Agar compositions Ingredients Gms/Litre Pancreatic digest of casein $15 \mathrm{~g} / \mathrm{l}$; Papaic digest of soyabean meal $5 \mathrm{~g} / \mathrm{l}$; Sodium chloride $5 \mathrm{~g} / \mathrm{l}$; Agar $15 \mathrm{~g} / \mathrm{l}$; Final $\mathrm{pH}\left(\right.$ at $\left.25^{\circ} \mathrm{C}\right) 7.3 \pm 0.2$. Minimal medium containing $\mathrm{K}_{2} \mathrm{HPO}_{4}: 0.5 \mathrm{~g} / \mathrm{l}, \mathrm{KH}_{2} \mathrm{PO}_{4}: 0.5 \mathrm{~g} / \mathrm{l}, \mathrm{MgSO}_{4}: 2.0 \mathrm{~g} / \mathrm{l}, \mathrm{CaCl}_{2}: 1.0$ $\mathrm{g} / \mathrm{l}$ and $\mathrm{NH}_{4} \mathrm{Cl}: 3.0 \mathrm{~g} / \mathrm{l}$ supplemented with $1 \%$ tannic acid ( $\mathrm{pH} 5.5$ ). All the chemicals used in this study were of analytical grade and procured from Himedia, India and Merck, India.

*Corresponding author: Nagarajan Kayalvizhi, Department of Zoology, School of Life Sciences, Periyar University, Salem, Tamil Nadu, India, Tel: 04272345328; E-mail: kayalvizhinagarajan@gmail.com (or) kayal@periyaruniversity.ac.in

Received February 01, 2017; Accepted March 22, 2017; Published March 25 2017

Citation: Rasiravuthanahalli KG, Revathi S, Rameshkumar N, Krishnan M Kayalvizhi N (2017) Digestion of Tannin by Bacteria Enterobacter cloacae from the Gut of Indian Mole Cricket (Gryllotalpa krishnani). J Bioprocess Biotech 7: 302. doi:10.4172/2155-9821.1000302

Copyright: (c) 2017 Rasiravuthanahalli KG, et al. This is an open-access article distributed under the terms of the Creative Commons Attribution License, which permits unrestricted use, distribution, and reproduction in any medium, provided the original author and source are credited. 
Citation: Rasiravuthanahalli KG, Revathi S, Rameshkumar N, Krishnan M, Kayalvizhi N (2017) Digestion of Tannin by Bacteria Enterobacter cloacae from the Gut of Indian Mole Cricket (Gryllotalpa krishnani). J Bioprocess Biotech 7: 302. doi:10.4172/2155-9821.1000302

\section{Strains and growth conditions}

These strains were originally isolated from insect gut and cultures were grown on medium for tryptone soya agar. All bacteria were incubated at $37^{\circ} \mathrm{C}$ in $24 \mathrm{~h}$.

\section{Isolation of insect gut}

The gut was isolated from of the Orthoptera insect, G. krishnani (i.e., during the active feeding stage). Prior to dissection, sterilized by wiping with $70 \%$ ethanol on the cuticle for 5 seconds $[9,10]$. Dissection scissors were used to cut laterally behind the head capsule and the gut was removed and washed in 1X PBS to remove the leaf litter. Then, it was transferred into a $1.5 \mathrm{~mL}$ micro centrifuge tube for further processing.

\section{Culturing of the gut microbiota and tannase plate assay}

The dissected gut was suspended in $10 \mathrm{mM}$ sterile phosphatebuffered saline (PBS) [11]. The guts were sonicated $(50 / 60 \mathrm{~Hz}, 117 \mathrm{~V}, 1.0$ Amps; Branson Ultrasonics, Danbury, CT) for $30 \mathrm{Sec}$, macerated with a plastic pestle, and vortexes at medium speed for $10 \mathrm{sec}$ to separate bacterial cells from the gut suspension were cultured immediately on nutrient agar plates and plates were incubated for $48 \mathrm{hrs}$ at $37^{\circ} \mathrm{C}$. Screening of the potent tannase producing bacterial isolates were screened for tannase activity by hydrolysis tannic acid different concentration of test $(0.25 \%, 0.5 \%, 0.75 \%$ and $1 \%)$. After incubation plate was flooded with thereafter, the isolation of tannase-producing bacteria was carried out on nutrient agar plates supplemented with tannic acid, tannin-protein complex; cleavage of this complex by bacteria producing tannase reddish brown color forms a zone of around the colonies.

\section{Biochemical characterization test}

Identification of tannase producing bacteria morphological and biochemical characterization: The isolated colonies were observed under microscope to obtain the colony morphology i.e., colour, shape, size, nature of colony and pigmentation [12]. The bacterial isolate were gram stained and observed under a high power magnifying lens in light microscope. The bacterial isolates were biochemically characterized by Indole, Methyl red, Vogesproskauer, Citrate utilization, Catalase, Urease, Oxidase test and Triple sugar iron agar.

Extraction of genomic DNA: The bacterial pellet was collected from the overnight culture by centrifugation at 10,000 rpm for $3 \mathrm{~min}$. The pellet was resuspended in $300 \mu \mathrm{l}$ of GBL buffer by pipetting and vortexing. Immediately, $200 \mu \mathrm{l}$ of chloroform and $150 \mu \mathrm{l}$ of $6 \mathrm{M} \mathrm{NaCl}$ were added and the tubes were inverted ten times. The mixture was centrifuged at 10,000 rpm for $5 \mathrm{~min}$. The supernatant was transferred to a fresh $1.5 \mathrm{ml}$ Eppendorf tube. An equal volume of absolute ethanol was added carefully down the wall of the tube. The mixture was centrifuged again at $10,000 \mathrm{rpm}$ for $5 \mathrm{~min}$ and the supernatant discarded. Subsequently, the precipitated DNA was pipette out to a new Eppendorf tube and washed twice with $70 \%$ ethanol by centrifugation at $5000 \mathrm{rpm}$ for 5 minutes. The pellet was air dried at room temperature for 10 minutes. Finally the pellet was dissolved in $50-100 \mu$ of TE buffer ( $\mathrm{pH} 8.0)$.

Yield, purity and integrity of DNA: The isolated DNA was subjected to spectrophotometric analysis (Ultrospec 2100, Amersham Bioscience, Hong Kong) to determine the quality and quantity. The DNA purity was determined from the ratios $260 / 280 \mathrm{~nm}$ (indicator of protein contamination) and 260/230 nm (indicator of organic solvent residues). The size and intactness of the isolated DNA was checked by agarose gel electrophoresis. The isolated DNA was loaded on $1 \%$ agarose gel stained with ethidium bromide $(1 \mu \mathrm{g} / \mu \mathrm{l})$ and run for 30 min at $60 \mathrm{~V}$, for image acquisition, a LAB India gel documentation system (Infinity, UK) was used. The isolated genomic DNA size was determined by using a $1 \mathrm{~kb}$ DNA ladder (Biotool, Spain).

PCR amplification of $16 S$ rDNA gene: The selected bacterium was identified on the basis of its 16S rDNA sequence. DNA from the bacterial cells was isolated using QIAamp DNA Purification Kit (Qiagen, Japan) and electrophoresed in agarose gel. Fragment of $16 \mathrm{~S}$ rDNA gene was amplified by PCR upto 30 cycles (using the following profile: initial denaturation, $95^{\circ} \mathrm{C}$ for $2 \mathrm{~min}$; final denaturation, $94^{\circ} \mathrm{C}$ for $30 \mathrm{~s}$; annealing, $52^{\circ} \mathrm{C}$ for $30 \mathrm{~s}$; extension, $72^{\circ} \mathrm{C}$ for 90 s; final extension, $72^{\circ} \mathrm{C}$ for $10 \mathrm{~min}$ ). Amplified PCR product was purified using Qiagen Mini elute gel extraction kit (Qiagen, Japan). Forward and reverse DNA sequencing reaction of PCR amplicon was carried out with 27F AGAGTTTGATCMTGGCTCAG and $1492 \mathrm{R}$ TACGGYTACCTTGTTACGACTT primers using BDTv3.1 Cycle sequencing kit on (ABI3730xl) Genetic Analyzer [13]. A single discrete PCR amplicon band of 1500 bp was observed when resolved on $1.2 \%$ agarose gel.

Phylogenetic analysis: The reference sequences required for comparison were obtained from the NCBI database (http://www.ncbi. nlm.nih.gov/Genbank). The aligned sequences were then manually checked for gaps in each row and saved in molecular evolutionary genetics analysis (MEGA) format using MEGA v.2.1 software. Pair-wise evolutionary distances were computed using the Kimura 2-parameter model [14]. To obtain confidence values, the original dataset was resampled 1,000 times using the bootstrap analysis method. The bootstrapped dataset was used directly for constructing the phylogenetic tree with the MEGA program or for calculating multiple distance matrixes. The multiple distance matrix obtained was then used to construct phylogenetic trees using the neighbor-joining method of Saitou and Nei [15]. All of these analyses were performed using MEGA v.2.1 [16].

Degradation of tannic acid by cell-free extracts: The experiment was performed in 2-ml-Eppendorf tubes in a final volume of $1.1 \mathrm{ml}$ containing $1 \mathrm{mM}$ tannic acid final concentration. This involved the addition of $45 \mu \mathrm{l}$ of $25 \mathrm{mM}$ stock solution of tannic acid (Sigma, Germany) to the cell-free extract. The mixture was incubated in the dark at $37^{\circ} \mathrm{C}$ for $18 \mathrm{~h}$. The reaction products were extracted twice with one third of the reaction volume of ethyl acetate (Lab-Scan, Ireland). The solvent fractions were filtered through a $0.45 \mu \mathrm{m}$ PVDF filter (Teknokroma, Spain) and analysed by HPLC.

HPLC analysis: The water soluble polyphenolic compound tannic acid treated with tannase enzyme was analyzed with high performance liquid chromatography (HPLC). The analysis was carried out on a Shimadzu chromatography equipment SPD-20A model with a UV visible detector and $\mathrm{C} 18(4.60 \mathrm{~mm} \times 250 \mathrm{~mm})$ column with LC-8A pump followed by solvent system using acetonitrile, water and ethanol (3:5:2) as eluent at a flow rate of $1.4 \mathrm{ml} / \mathrm{min}$ with a total running time of $20 \mathrm{~min}$. Detection was performed at $254 \mathrm{~nm}$.

Tannin degradation confirm to FT-IR analysis: In determining the possible functional groups FT-IR analysis was performed using Perkin Elmer's most power, which is used to detect the characteristic peaks and their functional groups. The vibration pattern that appears in the infrared spectra provides information about the chemical functional group of the sample. Tannase enzymes prepared and $500 \mu \mathrm{l}$ of $0.5 \%$ tannin acid was mixed together and incubated at $37^{\circ} \mathrm{C}$ for 30 
Citation: Rasiravuthanahalli KG, Revathi S, Rameshkumar N, Krishnan M, Kayalvizhi N (2017) Digestion of Tannin by Bacteria Enterobacter cloacae from the Gut of Indian Mole Cricket (Gryllotalpa krishnani). J Bioprocess Biotech 7: 302. doi:10.4172/2155-9821.1000302

min. A fraction of sample was encased directly in sample holder and spectra were scanned from $500-4000 \mathrm{~cm}^{-1}$.

SDS-PAGE and zymogram: The culture filtrate with tannase enzyme was lyophilized and an aliquot of 2 to $5 \mathrm{mg}$ was used for separation of the extracellular proteins by sodium dodecyl-sulphatepolyacrylamide gel electrophoresis (SDS-PAGE-12\% gel) [17]. The sample was mixed with SDS buffer without b-mercaptoethanol and heated for $5 \mathrm{~min}$ at $40^{\circ} \mathrm{C}$, and then loaded and run in Mini Protein II Electrophoresis unit (Bio Red) at $4^{\circ} \mathrm{C}$. The location of tannase activity within the gel was determined as described by Aoki et al. [18]. After electrophoresis, the gel was removed and washed for $1 \mathrm{~h}$ in 100 $\mathrm{ml}$ of $1 \%(\mathrm{v} / \mathrm{v})$ triton X-100 followed by 30 -min washes (twice) with $100 \mathrm{ml} 0.5 \mathrm{~mol}$ acetate buffer ( $\mathrm{pH}$ 5.5) with constant shaking. The gel was incubated with $0.5 \%(\mathrm{w} / \mathrm{v})$ tannic acid in $50 \mathrm{ml}$ of acetate buffer (pH 5.5) for $15 \mathrm{~min}$ at $25^{\circ} \mathrm{C}$. Tannic acid solution was discarded and subsequently the gel was rinsed with the same buffer and replaced with $0.5 \%(\mathrm{w} / \mathrm{v})$ quinine hydrochloride and incubated at $25^{\circ} \mathrm{C}$ to visualize the tannase enzyme activity on the gel.

Submission of GenBank: The bacterial 16S rDNA gene sequences from our effort were deposited in the GenBank Sequence Read Archive under accession number KX156583.

\section{Results}

\section{Isolation of tannase enzyme producing gut of G. krishnani bacteria}

G. krishnani was dissected in the laboratory conditions and plated in the trypton soya agar. Enumeration of microbial flora in the GI tracts of G. krishnani studied revealed that presence of bacteria in gut region was numerous. Maximum number of microbiota $\left(8.2 \times 10^{6} \mathrm{CFU} / \mathrm{ml}\right)$ was found in the gut of G. krishnani. It was observed that 5 isolates out of total 120 tested were able to show significant growth on tannase plate. The tannase producing bacteria were subjected to different substrate concentration of tannic acid $0.25 \%, 0.5 \%, 0.75 \%$ and $1 \%$ (Figure 1), further screened for their ability to degrade tannic acid by gel diffusion method (zone of hydrolysis). Out of these, 5 isolates (TAH 6 , TAH 13, TAH 36, TAH 38 and TAH 41) were found to be positive for visual detection method as indicated by a color change of the medium from red to brown color using tannic acid as the substrate. However, a distinct zone of hydrolysis on the agar plates could not be obtained by other bacteria's except TAH 41. TAH 41 bacterial strain showed clearing zone in all tannic acid plate tested and the results confirmed that bacterial strains were able to resist $1 \%$ tannic acid (Figure 2). Subsequently the five isolates were subjected liquid culture analysis, in this experiment TAH41 $(2.23 \mathrm{U} / \mathrm{ml})$, showed maximum activity others showed less activity. G. krishnani is the mainly concerned as much to seek in its digestive systems for the search of beneficial microbes which is responsible for the digestive a large amount of tannase producing microbes.

\section{Identification of bacterial TAH41 by biochemical and $16 \mathrm{~S}$ rDNA sequence analysis}

The gram-staining analysis observed to have a bacteria long rod with shape. The morphological, physiological and biochemical characteristics were carried out to identify the strain (Figure 3), the results showed a typical characteristic of Enterobacter cloacae (Table 1). The $16 \mathrm{~S}$ rDNA sequence of the bacterial strain was amplified using the universal primers 27 F' and 1492 R' from chromosomal DNA of the strain used as template, yield the amplification $1500 \mathrm{bp}$ was viewed

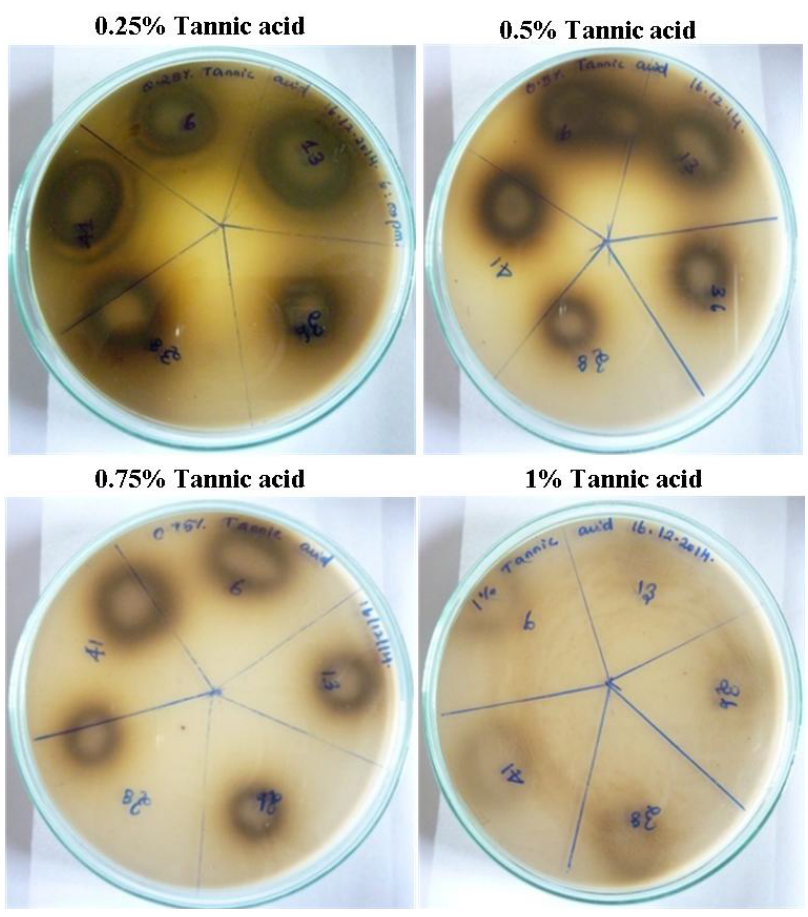

Figure 1: Efficiency of tannase-producing bacteria in different concentration of tannic acid. A- $0.25 \%$ Tannic acid; B-0.5\% Tannic acid; C-0.75\% Tannic acid; D-1\% Tannic acid.

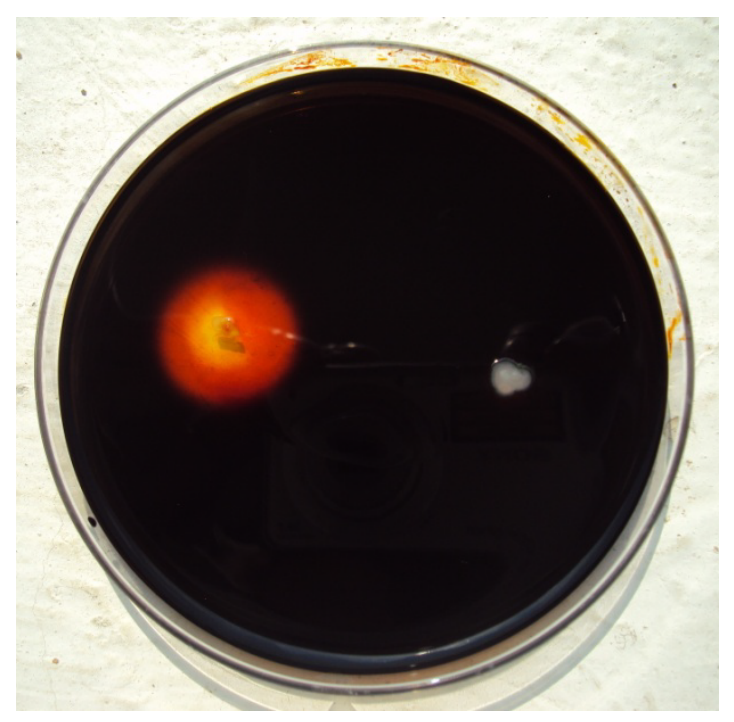

Figure 2: Tannase enzyme plate assay from Enterobacter cloacae.

in agarose gel electrophoresis (Figure 4). By performing a BLAST search in the Genbank data base analysis showed the strain belongs to Enterobacter cloacae. The phylogenetic tree was constructed by the neighbor joining method with respect to the phylogenetic tree of the $16 \mathrm{~S}$ rDNA among the strains is considered to be representative of the species (Figure 5).

\section{Tannase cell free extract to analysis HPLC}

HPLC analysis was carried out to show the degradation of tannic 


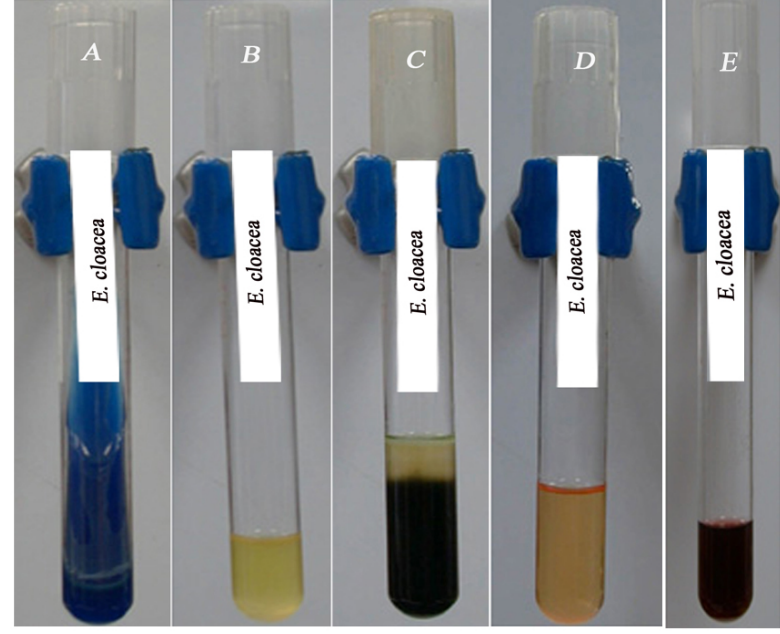

Figure 3: Biochemical analysis Enterobacter cloacae (A) Citrate test; (B) Methyl Red (MR); (C) Indole production; (D) Urea hydrolysis; (E) VogesProskauer (VP).

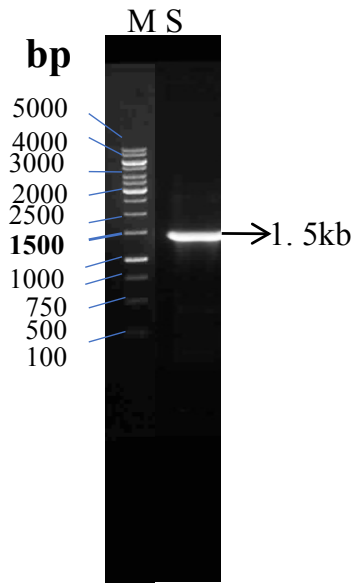

Figure 4: PCR amplification of 16S rDNA gene from insect gut microbes of $E$. cloacae.

\begin{tabular}{|c|c|}
\hline Colony & Morphology \\
\hline Configuration & Round \\
\hline Margin & Entire \\
\hline Elevation & Raised \\
\hline Surface & Smooth \\
\hline Pigment & Cream \\
\hline Opacity & Translucent \\
\hline Cell Shape & Shorts rods \\
\hline Size $(\mu m)$ & $0.5-1.5 \mu$ \\
\hline Arrangement & Occurring singly \\
\hline Biochemical test & Characterization \\
\hline Indole test & - Ve \\
\hline Methyl red test & - Ve \\
\hline Voges Proskauer test & + Ve \\
\hline Citrate utilization & + Ve \\
\hline Urea hydrolysis & - Ve \\
\hline
\end{tabular}

Table 1: Biochemical characterization of tannase enzyme producing $E$. cloacae. acid by the tannase enzyme of E. cloacae. The control tannic acid was quantified by $\mathrm{C} 18$ general purpose column using the solvent, the mobile phase is of solvent acetonitrile, water and ethanol $(3: 5: 2$, $\mathrm{v} / \mathrm{v} / \mathrm{v})$. The results are shown in Figure 6, the hydrolysis of tannic acid and the accumulation of galic acid is identified clearly. The presence of compound gallic acid was confirmed by an extended standard (gallic acid) in order to compared the retention time and to know the product accumulation. In the present work HPLC analysis revealed the formation of different peak with different chemical intensity along the fermentation between retention time of $2.5 \mathrm{~min}$. The shift in peak states that the tannase enzyme has hydrolysis tannic acid; similar research was stated by Rahman et al. [19]. The results showed tannic acid degraded into simple molecules. Tannase enzyme activity was notably present in the digestive system gut of microbes from Enterobacter cloacae many insects [20].

\section{Analysis of FT-IR tannase enzyme from $E$. cloacae}

The FT-IR analysis was performed for control tannic acid (T1) and treatment (T2) with tannase enzyme of strain E. cloacae for $1 \mathrm{hr}$ at $37^{\circ} \mathrm{C}$. The FT-IR spectrum of tannin samples was described by five main modes with maximum absorbance peak near 3500, 2500, 2000, $1500,500 \mathrm{~cm}^{-1}$ (Figure 7). FT-IR analysis of the tannase enzyme showed bands at $3432.03,2838.51,2086.85,1631.94,1367.17$ and $780.76 \mathrm{~cm}^{1}$, which reflected the presence of $\mathrm{H}$-bonded ' $\mathrm{O}-\mathrm{H}$ ' stretching, $\mathrm{C}-\mathrm{H}$ stretch, conjugated $\mathrm{C}^{1 / 4} \mathrm{O}, \mathrm{C}^{1 / 4} \mathrm{C}$ (aromatic), $\mathrm{C}-\mathrm{O}$ stretch and para $\mathrm{O}-\mathrm{H}$ (out of plane). The FT-IR result showed control tannic acid and treated with tannase enzyme exhibited a different pattern respectively that was correlated with the bonding pattern confirmed its presence. The FTIR spectrum was used to identify the functional chemical group of the active components based on the peak value in the region of infrared radiation

\section{Protein determination SDS-PAGE and zymogram analysis}

The E. cloacae apparently produced a single type of extracellular tannase, as evidenced by a single band of tannase enzyme activity in polyacrylamide gel electrophoresis and zymogram analysis. When the gel was activated with tannic acid and subsequently with quinine hydrochloride, it was rapidly covered with an insoluble complex of tannic acid and quinine hydrochloride. The complex was uniformly distributed on the gel, whereas some portion (3-5 $\mathrm{mm}$ ) remained transparent on the top of the gel without formation of the complex, which indicated that tannase enzyme activity appeared as a clear band on the gel approximately $\sim 45 \mathrm{kDa}$ (Figure 8 ).

\section{Discussion}

The insect gut of animals exhibiting a natural adaptation to dietary resources containing tannins could harbor valuable microbes and enzymes as augment livestock production [21]. Tannins have several important biological activities, such as a mechanism of defense against diseases caused by bacteria, fungi and viruses [22]. Bitter taste of tannin helps to protect plant tissues from the attack of insects and herbivores [23]. Moreover, gut anaerobes have also been isolated from non-ruminants which can dissociate hydrolysable tannins HT-protein complexes, but not the complexes of proteins with condensed tannins [24]. E. ludwigii GRT-1 isolate was found to grow as scattered cells when grown on culture media containing different levels of tannic acid $[25,26]$. Tannin-degrading bacteria, such as Streptococcus caprinus, Streptococcus gallolyticus, Streptococcus macedonicus, Selenomonas ruminantium has been earlier reported [27-29]. The fiber-degrading bacteria and fungi usually adhere to the surface of plant cell walls, and 


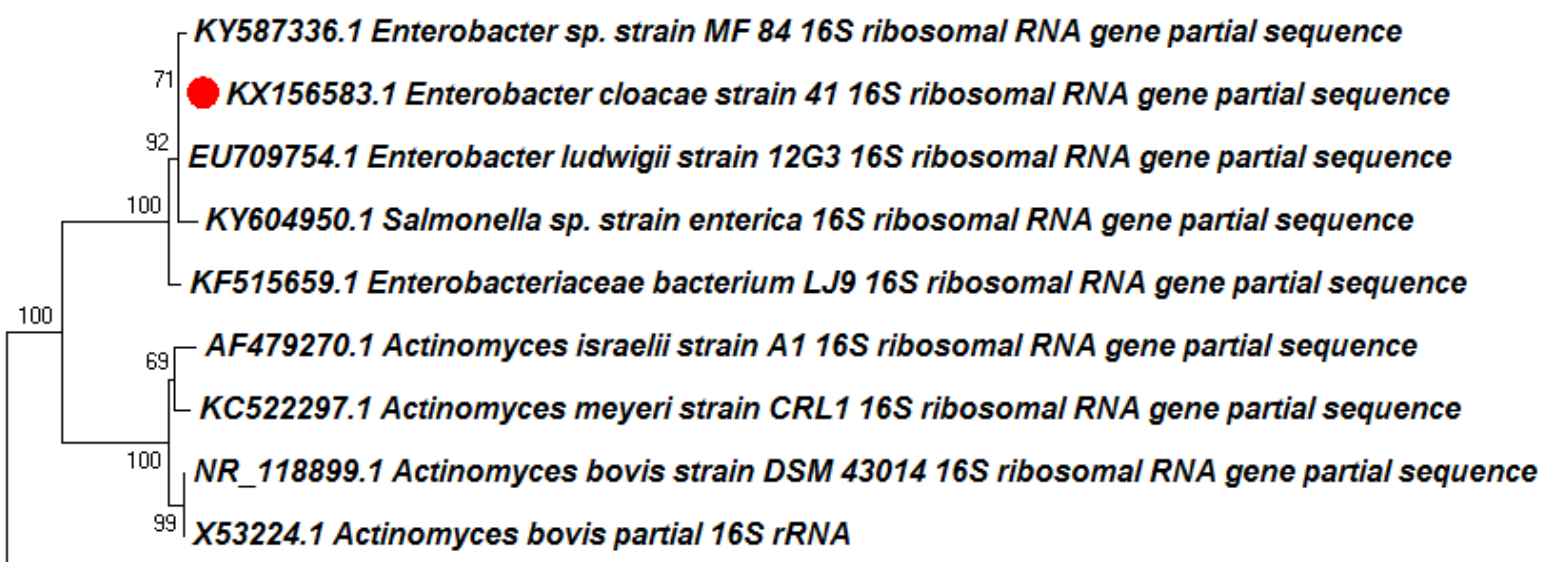

EU887827.1 Enterococcus faecalis strain H13 16S ribosomal RNA gene partial sequence

KX881079.1 Bacillus sp. strain KLP3 16S ribosomal RNA gene partial sequence

\subsection{2}

Figure 5: Phylogenetic tree based on 16S rDNA sequences for the gut microbes isolated from insect G. krishnani. The tree was constructed using the neighbour joining method. To obtain confidence values, the original dataset was resampled 1,000 times using the bootstrap analysis method.

A

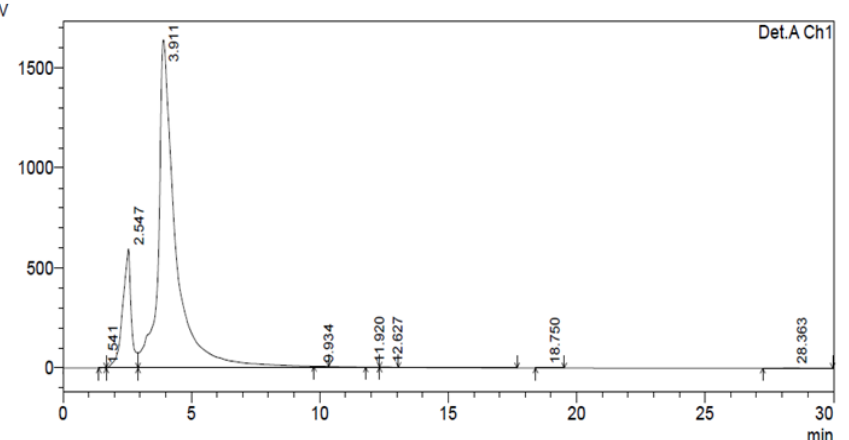

C

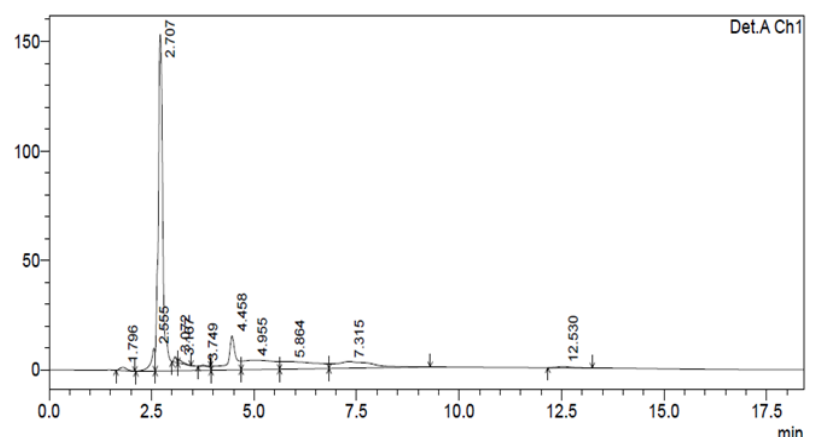

B

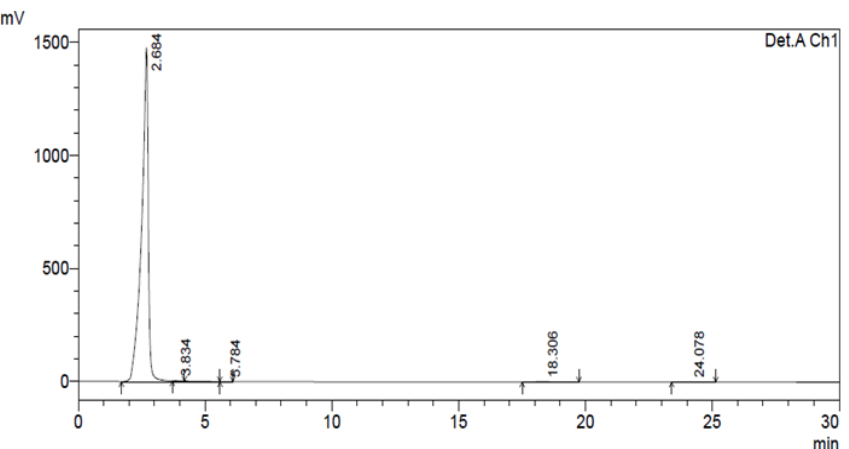

D

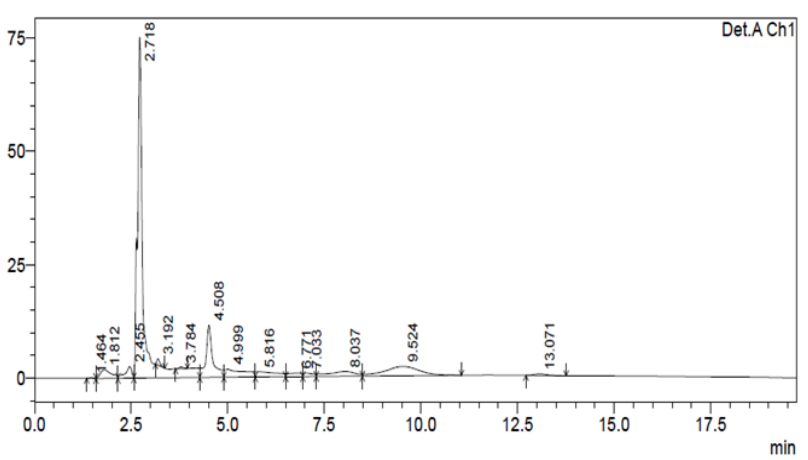

Figure 6: HPLC analysis of tannase enzyme (A) Tannic acid; (B) Gallic acid; (C) E. cloacae cell free extract tannase enzyme; (D) Treatment of tannase enzyme incubated for $60 \mathrm{~min}$ at $37^{\circ} \mathrm{C}$ in the presence of $1 \mathrm{mM}$ tannic acid. Detection was performed at $254 \mathrm{~nm}$. 


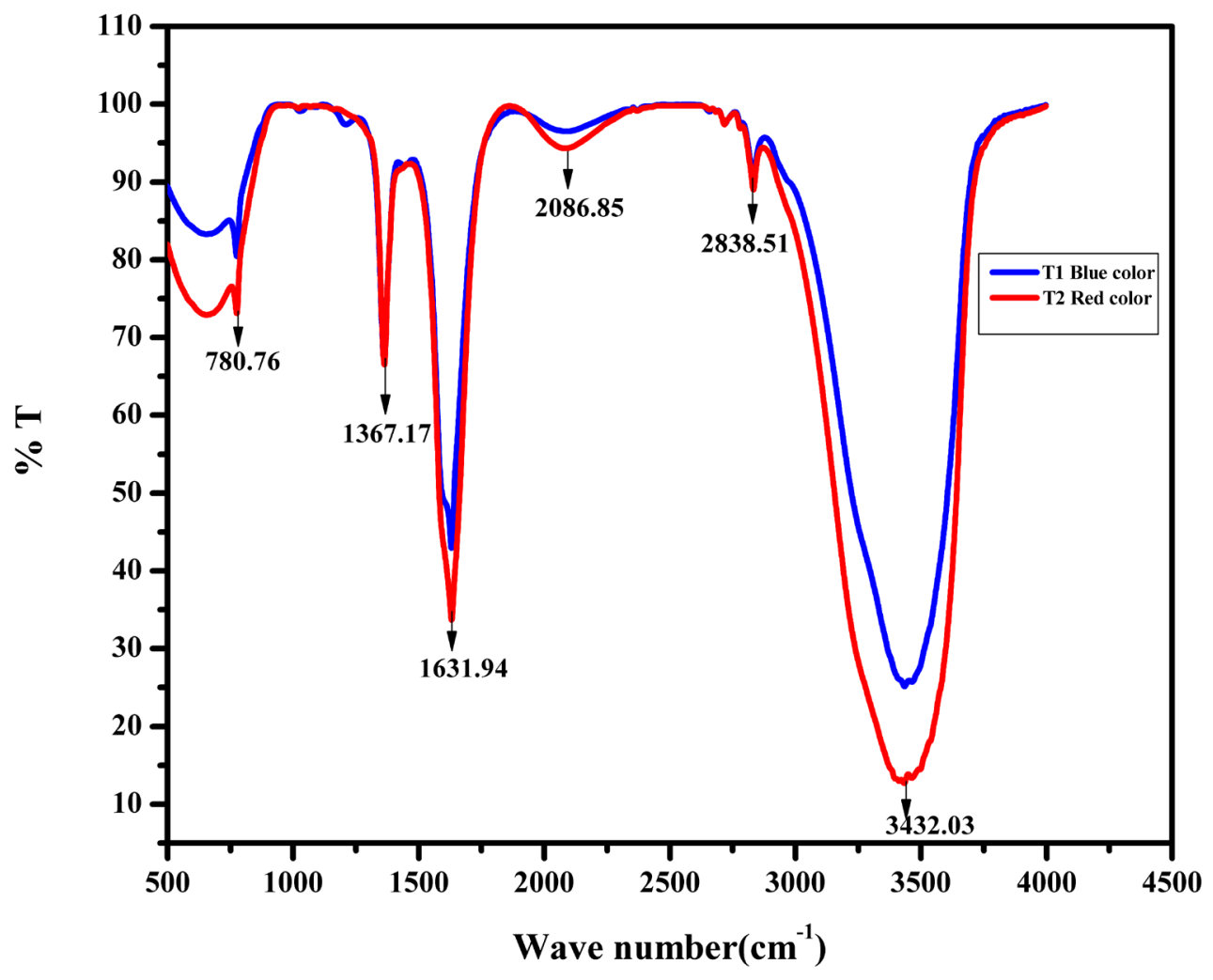

Figure 7: Tannase enzymes degradation to analysis FT-IR Tannic acid (T1) and Tannase enzyme treatment (T2).

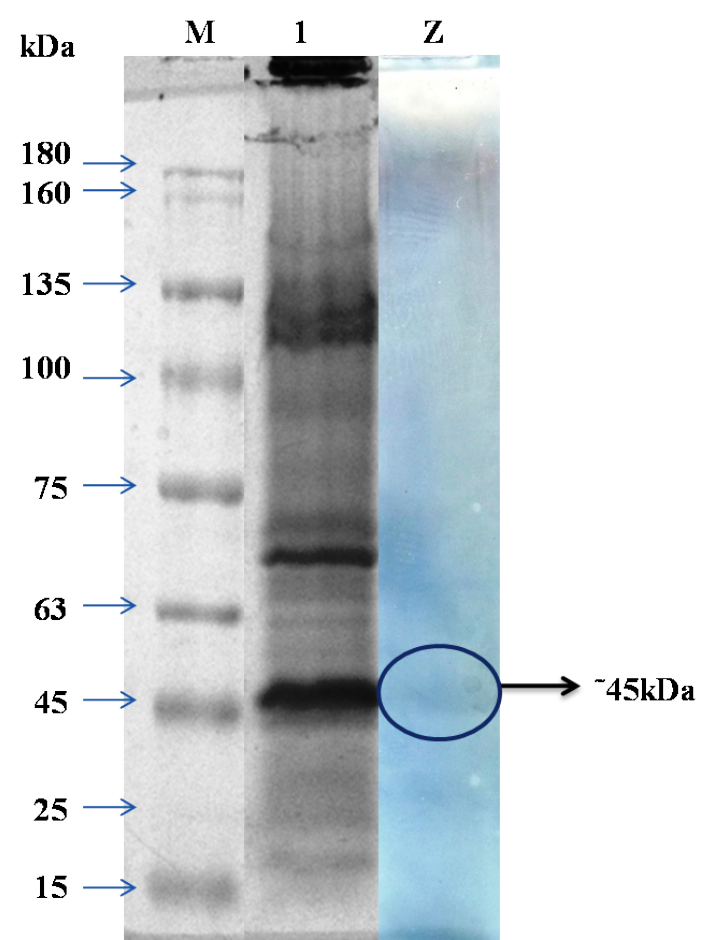

Figure 8: Molecular weight of $E$. cloacae tannase estimated by SDS-PAGE. (Lane 1) Marker proteins (kDa), (Lane 2) Crude extract CFE (Lane 3) Zymogram. a lack of understanding of how to exploit this process may be one of the reasons for the difficulty in establishing inoculants microorganisms in the rumen [30].

The study suggests that the tannase could be useful to synthesize molecules of pharmaceutical interest, and that tannase and Enterobacter sp itself could be used to protect grazing animals against tannins [31]. This is the first report on tannase activity of E. cloacae isolated from gut region G. krishnani insect. However, the present work is a preliminary study, and relevant to the screening of tannase plate assay microbial degradation of hydrolysable tannins (HT), and the physiological role of their metabolites in these animals requires further investigation [22]. The taking into account the tannic acid degradation observed by cell-free extract in the described experiment, we obviously confirmed for the first time that E. cloacae is able to extend degrade tannic acid. Previously a complex environment where both aerobic conditions prevail in the termite insect gut has been studied [32]. Abundant aerobic bacteria have been found [33].

The contribution of these bacterial populations to the hydrolytic enzyme has not been fully assessed. The FT-IR result showed control tannin treated to tannin with enzymes exhibited a different pattern. Previous reports that the variations in the absorbance at 3454, 2358, 2070, 1640, 667 state that the tannase enzymes degradable to tannic acid in the tannin complex compound [34]. This assumption is logical when one realizes that most industrial enzymes will necessarily have originated from the small percentage that has been cultured because of the poor ability to culture environmental microorganisms [35].

This observation is comparable with the earlier study by Mahendran 
Citation: Rasiravuthanahalli KG, Revathi S, Rameshkumar N, Krishnan M, Kayalvizhi N (2017) Digestion of Tannin by Bacteria Enterobacter cloacae from the Gut of Indian Mole Cricket (Gryllotalpa krishnani). J Bioprocess Biotech 7: 302. doi:10.4172/2155-9821.1000302

et al. [36] which showed that purified tannase from P. varoitii was present in a monomeric form the specific detection of tannase activity on the SDS-PAGE during zymogram analysis. Previously, Lactobacillus plantarum and K. pneumonia tannase were also found to be a monomer with a molecular mass of 46.5 and $50 \mathrm{kDa}$, respectively $[37,38]$. In insects the digestion of food by gut associated bacteria has been demonstrated in cricket's mole, germ free crickets have much less hydrolytic enzymes activity a conventional cousin and these bacteria help in utilizing a wide range of food substrate [22].

\section{Conclusion}

Screening of gut microbial from the insect G. krishnani revealed the presence of a diverse group of microbes producing tannase enzyme. In summary, tannase are an industrially important enzyme that is mainly used in the tannery effluent industry. As the range of applications of this enzyme is very wide there is always a search for novel tannase enzyme with better characteristics, which may be suitable in the diverse fields of applications. The present paper reports the isolation, identification and characterization of tannase from G. krishnani insect gut microbes Enterobacter cloacae. Hence, recent biotechnological intervention, genetic manipulation through bioinformatics prediction approaches must be made to enhance the functional property of tannase enzymes to exploit them for various industrial applications. With regards to tannase much of its activity, especially in the insect world, seems get to be explored.

\section{Conflict of Interest}

The authors declare that they have no conflict of interest.

\section{Acknowledgement}

The authors gratefully acknowledge the Department of Science and Technology, New Delhi for providing financial supports under SERB start up grant for Young Scientist (SB/YS/LS-141/2013) Scheme.

\section{References}

1. Aithal M, Belur PD (2013) Enhancement of propyl gallate yield in nonaquous medium using novel cell-associated tannase of Bacillus massiliensis. Preparative Biochem Biotechnol. 43: 445-455.

2. Lekha PK, Lonsane BK (1997) Production and application of tannin acylhydrolsase: state of the art. Adv Appl Microbiol. 44: 215-260.

3. Deschamps AM, Otuk G, Lebeault JM (1983) Production of tannase and degradation of chestnut tannin by bacteria. J Ferment Technol. 6: 55-59.

4. Govindarajan RK, Revathi S, Rameshkumar N, Krishnan M, Kayalvizhi N (2016) Microbial tannase: Current perspectives and biotechnological advances. Biocatal Agric Biotechnol. 6: 168-175

5. Beniwal V, Kumar A, Goel G, Chhokar V (2013) A novel low molecular weigh acido thermophilic tannase from Enterobacter cloacae MTCC 9125. Biocatal Agric Biotechnol. 2: 132-137.

6. Beniwal V, Sharma A, Marwah S, Goel G (2015) Use of chickpea (Cice arietinum L.) milling agrowaste for the production of tannase using co-cultures of Aspergillus awamori MTCC 9299 and Aspergillus heteromorphous MTCC 8818. Ann Microbiol. 65: 1277-1286.

7. Adams D, Douglas AE (1997) How symbiotic bacteria influence plant utilization by the polyphagous aphid Aphis fabae. Oecologia. 110: 528-532.

8. Broderick NA, Raffa KF, Goodman RM (2004) Census of the bacterial community of the gypsy moth larval midgut by using culturing and cultureindependent methods. Appl Environ Microbiol. 70: 293-300.

9. Pandiarajan J, Suganya T, Krishnan M (2014) Gut resident microbes in Groundnut pest Amsacta albistriga (Red Hairy Caterpillar). Curr Res Microbiol Biotechnol. 2: 340-346.

10. Arun Prasanna V, Kayalvizhi N, Rameshkumar N (2014) Characterization of amylase producing Bacillus megaterium from the gut microbiota of Silkworm Bombyx mori. Res J Chem Environ. 18: 38-45.
11. Sambrook J, Fritsch EF, Maniatis T (1989) Molecular cloning a laboratory Manual, II (Ed.). Cold Spring Harbour Laboratory Press. Cold Spring Harbour, USA.

12. Lu MS, Fang Y, Li H, Liu H, Wang S (2010) Isolation of a novel cold-adapted amylase-producing bacterium and study of its enzyme production conditions. Ann Microbiol. 60: 557-563.

13. Maity C, Samanta S, Halder SK, Das Mohapatra PK, Pati BR, et al. (2011) Isozymes of a-amylases from newly isolated Bacillus thuringiensis CKB19: production from immobilized cells. Biotechnol Bioproc Eng. 16: 312-319.

14. Kimura M (1980) A simple method for estimating evolutionary rate of base substitutions through comparative studies of nucleotide sequences. $\mathrm{J} \mathrm{Mol} \mathrm{Evol.}$ 16: $111-120$

15. Saitou N, Nei M (1987) The neighbor-joining method: a new method for reconstructing phylogenetic trees. Mol Biol Evol. 4: 406-425.

16. Kumar S, Tamura K, Nei M (2004) Mega3: Integrated software for molecular evolutionary genetics analysis and sequence alignment. Brief Bioinform. 5 150-163.

17. Laemmli UK (1971) Cleavage of structural proteins during the assembly of the head of bacteriophage T4. Nature. 227: 680-684.

18. Aoki K, Tanaka T, Shinke RL, Nishira H (1979) Detection of tannase in polyacrylamide gels. J Chromatogr A. 170: 446-448.

19. Rahman NA, Hasan M, Hussain MA, Jahim J (2008) Determination of Glucose and Fructose from Glucose Isomerization Process by High Performance Liquid Chromatography with UV Detection. Modern Appl Science. 2: 151-154.

20. Terra WR, Ferreira C, Jordao BP, Dillon RJ (1996) Digestive enzymes, In Biology of the insect midgut. Springer Netherlands 153-194.

21. Singh B, Gautam SK, Verma V, Kumar M, Singh B (2008) Metagenomics in animal gastrointestinal ecosystem: potential biotechnological prospects. Anaerobe. 14: 138-144.

22. Govindarajan RK, Revathi S, Rameshkumar N, Krishnan M, Kayalvizhi N (2016) Isolation and characterization of tannase producing bacteria from the gut of Gryllotalpa krishnani. J Microbiol Biotech Food Sci. 6: 813-817.

23. Arijit J, Suman KH, Amrita B, Tanmay P, Bikash RP, et al. (2014) Biosynthesis structural architecture and biotechnological potential of bacterial tannase: a molecular advancement. Bioresour Technol. 157: 327-340.

24. McSweeney CS, Palmer B, McNeill DM, Krause DO (2001) Microbial interactions with tannins: nutritional consequences for ruminants. Animal Feed Sci Technol. 91: 83-93.

25. Nelson KE, Pell AN, Schofield P, Zinder SH (1995) Isolation and characterization of an anaerobic ruminal bacterium capable of degrading hydrolysable tannin Appl Environ Microbiol. 61: 3293-3298.

26. Goel G, Puniya AK, Singh K (2007) Phenotypic characterization of tannin protein complex degrading bacteria from feces of goat. Small Ruminant Res. 69: $217-220$.

27. O' Donovan L, Brooker JD (2001) Effect of hydrolysable and condensed tannins on growth, morphology and metabolism of Streptococcus gallolyticus (S. caprinus) and Streptococcus bovis. Microbiol. 147: 1025-1033.

28. Goel G, Puniya AK, Singh K (2005) Tannic acid resistance in rumina Streptococcal isolates. J Basic Microbiol. 45: 243-245.

29. Hiura T, Hashidoko Y, Kobayashi Y, Tahara S (2010) Effective degradation of tannic acid by immobilized rumen microbes of a sika deer (Cervus nippon yesoensis) in winter. Animal Feed Sci Technol. 15: 1-8.

30. Wang L, Hatem A, Catalyurek UV, Morrison M, Yu Z (2013) Metagenomic insights into the carbohydrate-active enzymes carried by the microorganisms adhering to solid digesta in the rumen of cows. PLOS ONE: e78507.

31. Sharma KP, John PJ (2011) Purification and characterization from of tannase and tannase gene from Enterobacter sp. Process Biochem. 46: 240-244.

32. Brune A, Friedrich M (2000) Micro ecology of the termite gut structure and function on a microscale. Curr Opin Microbiol. 3: 263-269.

33. Schultz JE, Breznak JA (1978) Heterotrophic bacteria present in hindguts of wood-eating termites Reticulitermes flavipes (Kollar). Appl Environ Microbiol. 35: 930-936.

34. Hoong YB, Paridaha MT, Luqman CA, Koh MP, Loh YF (2009) Fortification of 
Citation: Rasiravuthanahalli KG, Revathi S, Rameshkumar N, Krishnan M, Kayalvizhi N (2017) Digestion of Tannin by Bacteria Enterobacter cloacae from the Gut of Indian Mole Cricket (Gryllotalpa krishnani). J Bioprocess Biotech 7: 302. doi:10.4172/2155-9821.1000302

Page 8 of 8

sulfited tannin from the bark of Acacia mangium with phenol-formaldehyde for use as plywood adhesive. Ind Crops Prod. 30: 416-421.

35. Yeung M (2012) ADSA Foundation Scholar Award: Trends in culture independent methods for assessing dairy food quality and safety: Emerging metagenomic tools. J Dairy Sci. 95: 6831-6842.

36. Mahendran B, Raman N, Kim DJ (2006) Purification and characterization of tannase from Paecilomyces variotii: hydrolysis of tannic acid using immobilized tannase. Appl Microbiol Biotechnol. 70: 444-450.

37. Iwamoto K, Tsuruta H, Nishitaini Y, Osawa R (2008) Identification and cloning of a gene encoding tannase (tannin acyl-hydrolase) from Lactobacillus plantarum ATCC 14917T. Syst Appl Microbiol. 31: 269-77.

38. Sivashanmugam K, Jayaraman G (2011) Production and partial purification of extracellular tannase by Klebsiella pneumoniae MTCC 7162 isolated from tannery effluent. Afr J Biotechnol. 10: 1364-1374. 